\title{
O [Queer] Pioneers! Narrating Queer Lives in Virtual Museums
}

Joshua Adair*

\begin{abstract}
This study examines the current approach of virtual museums in presenting the lives of queer subjects, especially when a subject's queerness is either almost completely obscured or seriously misrepresented in favor of a less controversial, more readily marketable version. Examining the Willa Cather Foundation virtual museum, this study critiques the selective erasure of various facets of historic figures' lives and explores alternative approaches to reconcile similar situations.
\end{abstract}

Key Words: queer theory, virtual house museums, Willa Cather

Instead of shying away from controversy, then, museums should embrace it for the lessons it can teach. No matter how carefully a historic house, historic site, or museum approaches a topic, someone is going to take issue with the way the story is told.

\author{
Rex Ellis \\ "InterpretingtheWholeHouse"
}

\section{Prologue: A Queer Pioneer}

I first read Willa Cather's O Pioneers! (1913) in an English class in 1991. Cather, a major figure in American literary modernism, is best known for that work and My Antonia (1918), as well as the later Death Comes for the Archbishop (1927). Her works frequently focus upon characters that have been repeatedly assessed as queer; she tends to focus upon unlikely or unusual friendships and the lives of single people. When I first encountered her work, I had little sense of the author or the magnitude of her stature as a literary figure in the United States, nor that her work was often lauded for its depictions of Midwestern farm life and the struggles inherent therein. In fact, I took little away from the book other than some vague images of the Nebraska prairie and an indelible impression of the unrelenting difficulty of farm life in a hostile environment. What I remember quite clearly, though, is that my teacher, a liberal, outspoken woman out of sync with the conservative values that characterized my Midwestern high school, provocatively announced to the class that Cather was a trailblazer, holding her own against fellow literary giants like Ernest Hemingway and F. Scott Fitzgerald, and that Cather had done so in spite of being a lesbian. While this was shocking news to me - I had never heard a teacher talk about a homosexual and would not again for many years - it was not exactly cutting-edge information: Sharon O'Brien had made this case in her 1984 article, "The Thing Not Named': Willa Cather as a Lesbian."

Fast forward twenty years: I had not thought much about Cather other than encountering her name occasionally some years earlier in my $\mathrm{PhD}$ coursework focused upon gay and lesbian literature. In conducting in-depth research and writing about historic house museums in the United States, though, my mind suddenly leapt to Cather and her work about pioneers and my own lingering impression of her as a queer pioneer depicting queer characters at a time when she risked much with little chance of gaining acceptance. So I started to delve into her life and 
work a bit, writing an earlier version of this essay based upon an analysis of The Willa Cather Foundation's virtual presence, dedicated to presenting the life of the author and exploring her works. I was surprised in 2011 to discover that the site did not appear to know-or at least admit to knowing — what my English teacher had two decades earlier; I was amazed to learn upon contacting major figures connected with the site and its physical counterpart that they were still treating Cather's sexuality as unestablished and therefore off limits for discussion. Undeterred, I wrote my essay anyway, focusing upon the question 'what happens when a museum refuses to acknowledge instances of gender non-conformity and issues surrounding sexuality about which a majority of people seem to be aware?'After all, a simple Google search of 'Willa Cather Lesbian' reveals dozens of sources that offer critical insight into her identity as a queer woman, including the following from Publisher's Weekly website:

Cather is now widely understood as a lesbian. She lived for 38 years in domestic partnership with Edith Lewis, a professional editor, in New York City. Lewis's editorial skills probably contributed to Cather's elegant prose style, as the two of them went over her novels together before publication. ${ }^{1}$

Considering the assertion made here, especially once we know that its authors, Andrew Jewell and Janis Stout, are prominent Cather scholars, it becomes quite difficult to reconcile why the site remains so aloof about this issue, particularly if her partner contributed in significant ways to her work, which the site and many of its contributors like to nominate as its primary focus.

As I wrote the essay, I considered a significant part of my duty to be establishing an unassailable justification for characterizing Cather as queer because no concrete, absolute evidence existed to support this claim, even though the best and brightest Cather scholars characterized her as same-sex attracted/lesbian/queer/non-heterosexual. I submitted the final essay to a journal in the summer of 2011 and waited; it was eventually rejected and the accompanying feedback indicated that I had no right to characterize Cather's sexuality in any way. One reviewer even suggested that new information might establish her as heterosexual after all. I sensed homophobia and resentment of a challenge to a well-established literary reputation, which is not terribly surprising as Cather scholarship centers upon Red Cloud, Nebraska, an area well-known for its social and political conservatism. I revised the essay and published an early version of it elsewhere. ${ }^{2}$ Then in April 2016, Museum \& Society got in touch requesting revisions; due to circumstances beyond their control my essay had been overlooked for several years. Surprised by this turn of events but happy to re-engage the subject, I once more returned to the world of Cather and the museum that endeavors to represent her life and work. In the five years since I originally wrote about this subject, a sea changed had transpired. Cather's nephew, the last named literary executor in her will, had died, leaving no one to stop her letters from being published. While there still remains much debate about the ethics of publishing these materials in face of Cather's stated intentions, one must also question why she preserved such materials if she wished them to remain unseen forever. In 2013, Andrew Jewell and Janis Stout published The Selected Letters of Willa Cather, finally laying to rest any question of the possibility that Cather was a heterosexual woman, even if scholars have yet to reach consensus about what term connoting same-sex attraction best describes her. Upon returning to The Willa Cather Foundation's virtual museum in April, 2016, which had undergone a large-scale overhaul in February, 2015, to gather additional information, I was surprised to discover that little had changed since I originally wrote about the site in 2011 . What follows offers a glimpse of the recent past and the present for one virtual historic site, which offers important insight for all extant and nascent virtual historic site museums.

\section{The Secret that Isn't One}

Queer museum practice in the United States where historic sites are concerned remains remarkably conservative overall and especially reticent when it comes to discussing and presenting matters of gender non-conformity and sexuality. In my 2010 book chapter examining the presentation of queer men in U.S. historic house museums, I reported that no sites, including ones where the owner's or owners' sexuality is well-publicized, were openly addressing gender and/or sexuality in their materials or narratives. As other kinds of museums begin to curate 
LGBTQ+-themed exhibits and programs and museums like The GLBT History Museum in San Francisco, California, increase the visibility and exploration of queer community and history, among other things, historic house museums and their online presences have largely avoided this type of exploration. This situation, however, has improved slightly since the publication of my chapter: a handful of historic house museums, including The Museum of the Shenandoah Valley $^{3}$, Beauport ${ }^{4}$, and Jane Addams Hull-House Museum ${ }^{5}$, all now actively present narratives about former owners' sexualities. These changes are reflected in these museums' virtual presences as well as their physical sites, and all three have received considerable attention mostly popular - for their efforts. Other entities in the U.S., like the National Parks Conservation Association, have also begun to make concerted efforts to represent LGBTQ+ history at places like the Stonewall Inn, site of the 1969 riots that many credit as being the birthplace of the gay rights movement.

The American Alliance of Museums has also made major steps towards fostering greater inclusivity for LGBTQ+ people by publishing Welcoming Guidelines for Museums in $2016 .{ }^{6}$ A preview of the document offered in Museum in 2016 outlines strategies for practitioners to make diversity a 'strategic priority,' that should be both purposeful and encouraging. Its authors further assert that such changes will be 'scalable, with adoptable suggestions for museums of all sizes' (34). While it appears that the document will focus primarily upon strategies for welcoming LGBTQ+ visitors and facilitating 'diverse recruitment and hiring,' the further implication that museums - all museums - must also begin to consider how to explore issues of gender non-conformity and sexuality in curatorial practice, when relevant, cannot fall far behind. Such changes, one would think, will prove especially beneficial to virtual museum sites, as competing, often contradictory, narratives assail any user interested enough to enter even the most elementary terms into a search engine like Google. Were I a high school or university student reading $O$ Pioneers! today, I can easily imagine myself conducting such a search and asking a quite pertinent question considering the results: why do the majority of virtual museums in the United States opt not to address gender non-conformity and sexuality in a straightforward, meaningful way in their virtual presences, even if they opt not to deliver any definitive answers?

I focus here specifically upon the virtual presences of historic house museums of queer subjects because very little critical attention has been directed to these sites despite the fact that more appear online each year and also because these virtual museums serve as the 'official' - which is often interpreted by users as the most reliable and trustworthy - source of information for visitors. As a visitor resource these sites serve two integral roles: first, they can help interested users prepare for an actual site visit; second, they serve as an alternate option for those without the means or ability to travel to their physical site(s). When potential physical site visitors encounter silences about certain kinds of information and inquiry that appear incongruous when compared with other online sources, sites run the risk of alienating those visitors and nurturing a sense of mistrust about the veracity of information that visitor might encounter while engaged in a tour. Such silences and exclusions operate similarly for virtual site-only visitors, as most users cannot help but engage with the fact that the 'official' source appears to be avoiding what many other sources that may be considered 'authoritative' are not. I draw this distinction her between 'official' and 'authoritative' to illustrate the fact that a virtual presence created and hosted by a historic site enjoys the privilege of delivering what most users will consider the most informed, credible, and thorough account of the individual's life whose representation justifies the entity's existence. This is not to say, however, that other 'authoritative' - informed, credible, thorough - sources do not compete for attention in a highly populated online environment, but they do not enjoy the cache conferred by working from within the site itself. 'Official' sites, then, must ensure that visitors encounter timely, critically informed narratives that present a polyphony of voices and which engage conflicting perspectives to encourage critical thought and discussion where no definitive answer exists.

In the last decade, a handful of scholars have turned their attention to the narratives delivered by historic house museums (Foy 2002; Pustz 2009; Adair 2010; Oram 2011, 2012). Most house museum scholars instead focus upon the necessity of preservation/conservation of these frequently under-funded sites (Butcher-Younghans 1996; Harris 2007: Merritt and Reilly 2010). Historic house museums represent only a fraction of U. S. museums, but they 
offer important insight into the lives of historic figures and offer opportunities for visitors to conceptualize the past through exhibitions, narratives, and the interpretation and juxtaposition of objects. Since their inception in the Civil War era, though, they have tended toward what Alison Oram characterizes as 'deeply conservative sites of public history' (192). She further observes, 'The stress on the genealogy of the elite families who have inhabited them is strongly heteronormative, and they have certainly been less permeable to the now well-established social histories of class, gender, colonialism and sexuality' (192). Rex Ellis has convincingly argued that historic sites often avoid addressing issues that might best be described as falling under the umbrella term of diversity - in which I would include gender non-conformity and sexuality-due to a lack of conclusive evidence. He argues that this presents an opportunity, and I concur, for historic sites to illustrate for visitors 'that history is a series of puzzle pieces' (67).

In other words, rather than conceiving of a historic site as a static place with an unchanging narrative to be recapitulated, as historic house museums so frequently and their virtual presences have done, they must begin to respond to new technology and changing visitor demands to ensure their role as a dynamic participant in discourses about history, posing questions and offering a range of interpretive possibilities for visitors.

As an important resource for researchers, a house museum must offer as comprehensive and complex a depiction of its subject(s) as possible. In 'Digital Museums and Diverse Cultural Knowledges: Moving Past the Traditional Catalog,' Srinivasan, Boast, Furner, and Becvar observe, 'some underlying contradictions must be resolved between museum practices, which privilege the account of the "expert," and distributed social technology practices, whose strengths lie in allowing for many, sometimes contradictory, perspectives' (265). In other words, because the goals and delivery methods of museums have changed drastically in the last decade, every approach must be interrogated and, in many cases, altered to present less definitiveness and greater possibility, even at the expense of expressing uncertainty and inconclusivity. Whereas in the past inconclusive information about gender non-conformity and sexuality routinely meant silence on the subject, now it must signal an opportunity to present and discuss a range of possibilities. Srinivasan, et al. note,

Every sequence of knowledge-claim takes the form of a narrative or story by which the nature of the objects of the knowledge-claim may be understood, explained or accounted for. Such narratives are endless, unstable, and context dependent (i. e. they are chronologically, geographically, and culturally specific) (267).

Thus, to offer sound 'authoritative' narratives, virtual museums must relinquish any claim, explicit or implicit, to a single, contradiction-free, deceptively coherent 'official' narrative. Elisa Giaccardi, in 'Collective Storytelling and Social Creativity in the Virtual Museum: A Case Study' argues that 'The virtual museum becomes a system of interconnections, allowing individuals to identify and locate resources' (31). She continues,

The idea of iridescence, in contemporary museology, refers to the fact that the perception of cultural objects (how we 'see' them) is subject to change according to the different perspectives in which they can be interpreted and presented. Normally, this perception is the result of the cultural and historical interplay among the physical tangibility of the artifact (the 'physical' component) and its future interpretations and meanings (the 'virtual' component). Today, by means of information and communication technologies, we can make these components interact more dramatically. (33)

Giaccardi's concept of 'iridescence' offers a particularly rich metaphor for the experiences of curation, interpretation, and collation. As James H. Sanders III notes in 'Queering the Museums,' 'Proliferating queer readings of museums and their historic, curatorial and educational practices could benefit both those engaged in museums and cultural studies, and those subjects challenging heterosexual norms' (par. 4). ${ }^{7}$ As I see it, then, those sites which enjoy 'official' status by virtue of their physical control of the historic site itself, must then employ their unique positioning to relinquish their insistence upon delivering what typically has been a singular narrative, couched in coherence and absolutism, sleek in its digestibility, 
if lacking in its engagement of nuance, possibility, and even incoherence. When it comes to issues of gender non-conformity and sexuality as they existed in the somewhat distant past, definitiveness rarely exists, but we frequently catch glimpses of lives lived in ways that did not appear to adhere to traditional narratives of gender and sexuality. Clues abound in many cases and rather than dismissing those possibilities as irrelevant because they cannot be substantiated absolutely, we must reframe our thinking and embrace the value of exploring possibility, of highlighting those moments when an object or subject iridesces.

One possible way of achieving this goal is by introducing the notion of 'queer spectrality' as Alison Oram outlines it in 'Going on an Outing: The Historic House and Queer Public History':

While identification involves looking for some elements of past similarity in the expression of same-sex desire, this approach does not, and cannot, simply reduce the past to the present, for the queer historic house visitor. The process of mimesis-comparing the self to the image of those past figures, or seeing their relationship as a copy of those in the present-breaks down at the moment it is attempted. (198)

Visitors, myself included, may sense some resonances with a particular historical figure, they may even glimpse some shadow of recognition or possibility of non-normative gender and/or sexuality because we ourselves fit into such categories and are keen to establish such linkages with the past. Such endeavors, I would argue, help establish a kind of removed continuity for certain kinds of people who long to identify with the past and see how other queer people may have pioneered our present. For those who do not fall into that category, though, such spaces, virtual and physical, operate as places of possibility, too, in the sense that they can illustrate the possibilities of social justice by rendering characterizations of individuals who navigated inhospitable and unenlightened worlds and managed to achieve some success in spite of - or in some cases, because of - their sexual or gender differences.

Oram's conception of the queer specter, drawn from the work of Carla Freccero, acknowledges a desire of contemporary individuals to find some thread of unity between the past and the present - a fundamental human impulse - but it resists any impulse to locate the identical. While historic house museums may be 'haunted' by remnants, fragments, or impressions of past inhabitants, visitors can never claim full access or authority about the biographical data of that life. Using this approach, it then becomes the museum's mission to enliven, not simplify, the past, and to introduce narratives of debate about the issues at hand, and then to contextualize the ways various societies have constructed, enforced, and marginalized various identities. This role as I and others like Oram have proposed it moves agency for museum staff at all levels from that of being gatekeepers, privileged purveyors of the so-called real story and places it in the realm of shared responsibility in which all participants - museum staff, visitors, online users - play a role in creating meaning out all available resources. Furthermore, such a shift in roles then facilitates direct engagement with members of the minority group being represented - a practice that has been successful with Native Americans and other minority groups in the U.S. as they collaborate with museums on representation of their people, customs, and beliefs - by inviting them to participate in a collective effort to critically, creatively, and thoughtfully represent the individual(s) connected to the space.

Oram suggests that there are three key aspects of the historic house we must consider as we advocate for changes in practice and interpretation: 'its existence in time and space, its interpretation as a museum, and how it is experienced by the visitor' (2012 535). I appreciate and wish to highlight the interpretive and experiential aspects of historic house museums, as they prove crucial to subjective nature of museum-going and meaning-making whether we physically enter such spaces or immerse ourselves in them online. What we bring to these experiences matters a great deal, just as what information and objects museum staff reveal or keep hidden drastically alters our understanding and appreciation of subjects we have approached in hopes of understanding better. These spaces, and their virtual counterparts I would argue, operate as what Jennifer Eichstedt has labeled 'dialogic spaces,' and we must do our best to make sure that practice such approaches, especially in regards to issues like 
gender and sexuality as they continue to dominate national and international discourse in many arenas. By complicating and critically analyzing the objects, spaces, and information we possess about historical personages who may have been queer, and I use the term here in the broadest sense possible, we may establish greater relevance for the historic house sites that many critics construe as little more than dusty relics from the past. In addition, we revitalize historic house museums as sites of education, dialogue, and even experimentation active in and connected to the contemporary world, capable of contributing to social justice movements by offering unique perspectives on our understandings of the past and its connection to the present. As Don Romesburg reminds us, 'Mainstream museums increasingly mount GLBT-related shows and will always play a crucial role in winning converts, solidifying GLBT legitimacy, and creating threads for our belonging in the tapestry of history' (131). Historic house museums, I submit, both in person and online, ought to endeavor in to play an identical role.

\section{Willa's Case}

The Willa Cather Foundation is a not-for-profit organization dedicated to preserving and promoting understanding and appreciation of the life, time, settings, and work of Pulitzer Prize-winning author Willa Cather. ${ }^{8}$

The case of the Willa Cather Foundation virtual museum proves fascinating: it delivers a wealth of information about, and praise for, the literary giant while avoiding presenting what many, myself included, argue are integral features of her life. The visually impressive site presents vintage photos, PDF files of artifacts, floorplans and photos of Cather's childhood home, as well as extensive scholarly resources and documents related to the history and development of the Foundation. The sheer volume of material presented on the site underlines its dedication to providing a rich experience for its users, except for those interested in learning about Cather as a queer subject. This, of course, raises the question: is it responsible to name Cather a queer subject? Or, is it possible that, as Oram would suggest, a queer specter of Cather deserves legitimate attention?

The vast body of scholarship about Cather and her work suggests, rather overwhelmingly, that, at the very least, an in-depth discussion about aspects of queerness in her life could prove productive and enlightening. David Porter, author of On the Divide: The Many Lives of Willa Cather (2008) asserts, 'The fact that as a lesbian she often felt alienated from society, queer, both added to this sense of division (of public and private selves) and encouraged her to explore it in her writing' (XX). Marilee Lindemann's, Willa Cather: Queering America, suggests queerness from its cover photo alone: Cather sporting a masculine hairstyle, looking remarkably 'butch.' Lindemann argues that Cather frequently presents queer characters and that she herself was likely queer:

Cather, whose sexual coming-of-age as a woman who loved women occurred in the midst of the transition from romantic friendship to sexual deviance and whose literary career is both a celebration and a fierce, fearful critique of the emerging nation. In a direct and personal sense, then, America 'queered' Cather by labeling her erotic identity deviant, "unnatural," as she herself put it in a crucial letter of 1892. (4)

Numerous others take up this thread and offer serious, well-researched arguments for considering Cather as, at the very least, non-heterosexual and non-heteronormative. Other notable treatments of Cather's queerness include Sharon O'Brien's Willa Cather: The Emerging Voice (1987), which includes a compelling analysis of extant romantic letters to Louise Pound, a schoolmate of Cather's (128-136); John P. Anders's Willa Cather's Sexual Aesthetics and the Male Homosexual Literary Tradition (2001); Jonathan Goldberg's Willa Cather and Others (2001); and Julie Abraham's Are Girls Necessary? Lesbian Writing and Modern Histories (2008).

In addition to those traditional scholarly publications about Cather, there a number of other authoritative online sources about her which prove particularly important because they present a widely accessible virtual dialogue. They spark a direct conflict between 'official' and 'authoritative' narratives while fostering a moment of that 'incandescence' described earlier because these sources represent a range of opinions and potential meanings. One site, 'The 
Lesbian Ghosts of Red Cloud, Nebraska,' gestures, if unintentionally, toward 'queer spectrality.' Created by Timothy Schaffert, an associate professor of English at the University of NebraskaLincoln, the page relates the experience of touring Red Cloud:

\begin{abstract}
Depending on your guide, you'll be told, should you ask, that Cather wasn't a lesbian, but rather was in a "Boston marriage" with editor Edith Lewis, the woman she lived with for over thirty years. As a gay man originally of small-town Nebraska (I grew up on a farm about an hour's drive from Red Cloud), I could be aggravated by this, but nonetheless I enjoy it_-it feels like a refusal that embraces, in a creaky Midwest tradition of silent anxiety. Calling the Cather-Lewis partnership a Boston marriage is a creative way of both denying (for the squeamish) and affirming (for the liberated). A marriage between two women, Boston or otherwise, is typically an indication of bald-faced lesbianism; the "Boston" part even adds a nod of civility and approval. ${ }^{9}$
\end{abstract}

Even if the curators of willacather.org avoid the allegations raised by Schaffert and others, it makes good sense to acknowledge them at least - if only through hyperlinks to authoritative materials on the subject - as they represent a school of thought considered reasonable by many authorities. Unquestionably, ignoring Cather's queerness and the body of literature addressing it only impugns, at least in part, the site's validity. It also sends the message that reading Cather as a queer subject might somehow diminish her stature as a literary figure, despite the site's claim to focus upon more than just her work.

The Cather Foundation site, despite its odd silences, stands as one of the bestdeveloped virtual historic site presences and could easily serve as a model for other historic sites in many ways. Its entrance imposes in much the same way an actual historic site's often does, highlighting the formidable entities responsible for its content and maintenance, including The Nebraska State Historical Society, The United States Department of Agriculture, The National Endowment for the Humanities, and The Nebraska Arts Council. These groups convey prestige, certainly, and their connection to state and national governments lends an air of prestige and authority - setting the stage for the delivery of its "official" narrative - to this enterprise. Centered on the homepage after the 2015 renovation of the site is a quotation from an interview with Cather: 'A book is made with one's own flesh and blood of years. It is cremated youth. It is all yours - no one gave it to you,' suggesting that the author and her work - at least in her estimation - are inextricably linked and if there is any chance that Cather's much-lauded work might be influenced in any way by her queer perspective, we would do well to explore what that might mean, even if only in the subjunctive mood.

Its landing page sets the mood of the current 'authoritative' narrative, one focused on a (not the, even if they would suggest otherwise) Cather narrative couched in conservatism and tradition. While in July 2011 it featured the photo of a 'respectable' middle-aged Cather superimposed upon a horizontally scrolling photo of the Nebraska prairie, juxtaposed against a hand plow graphic and Cather quotations, the updated version highlights specific events while still dedicating a space for that same Cather photo. It's clearly an expensive endeavor - one that easily outshines many others of its kind - with its glossy professional design and sophisticated navigational tools. In July, 2011, using the site's search function, a query of the term 'queer' returned 48 hits: some occurrences are traditional adjectival uses of the term, and the remainder referenced inaccessible conference papers or publications. As of April, 2016, there are only 40 references, but those materials are now available to searchers in the form of PDFs, which does suggest some progress. In 2011, 'lesbian' garnered one hit: a conference paper from the $13^{\text {th }}$ International Willa Cather Seminar called 'Willa Cather, Sarah Orne Jewett, and the Historiography of Lesbian Sexuality.' While the title sounded promising, the paper was inaccessible and there was no further mention of queerness, sexuality, gender, or any allied subject on the site, which created a rather pointed silence amidst the cacophony of 'authoritative' voices elsewhere online either referencing or directly discussing the issue. In 2016, 'lesbian' returns 29 results, all available in PDF, and many of which address Cather's sexuality in some form or another, which is easily discerned even with a cursory glance. I see 
this development over the last five years as both positive and problematic, as it suggests that the Foundation itself is now participating in the process of providing contradictory information to its users, as Cather's biography on the site still does not approach this topic. What are users to make of this information that can now be found if they know what to look for, but then must realize that the sites curators do not see fit to volunteer, even as a potential point of dialogue?

Despite this silence, however, specters of Cather's queerness - to conjure Oram's notion - appear sporadically throughout the site. In the 'gallery' section, if one clicks on 'Willa Cather,' a selection of photographs appears (84 in 2011; 65 in 2016). Only one photograph belies queerness: a snapshot of Cather looking sternly masculine in a Confederate Army cap and captioned, 'Willa Cather in Confederate Uniform,' offering no further context or discussion. Its iridescence captivates: could this photo initiate conversations about clothing's role in constructing and performing gender? What was Cather's perspective regarding the Civil War? What role does social location play and how do contextual clues help us initiate a dialogue about such a provocative photo? Visitors here need not receive definitive answers, only be provoked by interpretive possibilities.

The remaining 83 photographs available in 2011 presented a fairly stereotypical looking woman either as a very young girl or as a woman in middle age. Most of the pictures even today are quite small-about 1" $\times 2$ "-and enlarging them only increases their size incrementally. Thus, in cases where the photographs might suggest queerness as manifested by gender rebellion or gender nonconformity, it is impossible to closely examine photographic details. Other instances of investigating queerness, though limited, are quite revealing. The landing page highlights 'Rediscovering Serena's Album,' which illustrates Cather's gender non-conformity:

In 1888, a teenager signing herself "Wm. Cather M. D." made a memorable entry in a friendship album owned by her schoolmate Serena White. And Willa Cather's radiantly confident entry in Mental Portraits in only one of the jewels in its pages. Thanks to the generosity of Serena's family, you can discover for yourself the treasures in its pages, in this first-ever presentation of Serena's album in its entirety.

Impressive in its PDF format, the album offers a fascinating glimpse into a social custom at the time. Cather's entry proves remarkable - even radical - both because she poses as a male doctor, and because her answers register as markedly masculine. The journal includes the preprinted lines 'the trait I most admire in a woman' and 'the traits I most admire in a man,' to which Cather responds 'flirting' and 'an original mind,' respectively. She also indicates a desire for 'lamb like meekness' 'in a matrimonial partner.' Finally, Cather cites 'the greatest folly of the Nineteenth Century' as 'dresses \& skirts,' which while this could be interpreted as a modern perspective today still appears incongruous at the time for a woman the site presents as reasonably traditional. With cursory research throughout the site, it proves simple to make the claim that Cather exhibits gender non-conformity for a young woman of the period. In fact, many of her behaviors and responses appear to align more closely with stereotypical middle class masculinity at the time. This difference in outlook or temperament is brought into high relief when one examines entries by young women of similar age who have responded predictably and very differently from Cather. The presentation of this artifact remains unchanged from 2011-2016.

From the inclusion of the artifact, one might argue that the curators of this virtual museum are, in some limited fashion, not fully obscuring Cather's queerness. However, the introductory materials for 'Serena's Album' clearly presents a specific, and I would argue limited and limiting, perspective:
Albums like Serena's gave their users - mostly young and mostly female - the opportunity to put on performances for their friends, trying on identities and experimenting with self-invention and self-concealment. Many of the young people who signed Serena's album display a youthful bravado that stands out boldly against the sentimental backdrop of the album itself.

Cather's entry alone exhibits queer tendencies in breaking away from the predictable. By encouraging visitors to conceptualize the album only as a site of creative exploration, the introduction's author either avoids or dismisses opportunities to discuss Cather's queerness 
head-on by offering multiple iridescent interpretations or by establishing connections with other 'authoritative' narratives - those offered by Lindemann and Goldberg, for example — that might further elucidate the context of the artifact. Instead, the author suggests Cather was merely play-acting to amuse her friends, ignoring that her inscription might serve a more personal or even political purpose, and that she possibly was sincere in her assertions.

Furthermore, on the "Willa Cather Timeline" page, the author, again unknown, offers a fascinating entry for 1888 :

Having made up her mind to become a surgeon (an occupation considered at the time to be exclusively for males), Cather crops her hair short, dresses in the male fashion, and refers to herself as "Wm. Cather, M.D." and "William Cather, Jr." Cather also experiments with dissection and vivisection. At the Opera House, she and the Miner girls perform Beauty and the Beast to help the victims of the 1888 blizzard. Donning suit, top hat, and wax mustache, Cather plays Beauty's (Margie Miner's) merchant father.

Rather than allow that Cather may have enjoyed dressing in masculine attire and expressing masculine affect, the author carefully delivers these facts and, by way of the parenthetical remark, immediately explains away this behavior before the sentence concludes, lending it a decidedly defensive air. The author suggests a clear cause and effect: Cather wished to become a doctor, thus she emulated her role models. While I do not doubt this may be a possibility, it is certainly not the only one. Positioned in this way, Cather's choices appear as the expression of adolescent immaturity. As a result, the features of Cather's behavior which might be read or interpreted as queer are dismissed preemptively, foreclosing the potential for alternative syntheses of the material at hand.

Whether the avoidance of dialogue regarding queerness in the Cather museum is the product of fear surrounding a loss of funding, or prudishness, or a moral objection, visitors to the virtual museum cannot know. Unfortunately, this approach to relating Cather's story perpetuates a long history of silence, indifference, and contempt for those individuals who disrupt or challenge heteronormativity. Such dissonance between 'official' and 'authoritative' narratives highlights institutional hypocrisy: when a rudimentary web search significantly complicates and calls into question the image of the figure presented on the Cather website in a matter of seconds, what kind of damage does this realization cause to the authenticity and validity of the endeavor of the Cather Foundation to present history, encourage learning, and foster inquiry? I cannot help but think that the dissonance between these competing, rather than complementary, narratives instills mistrust in users of the site and visitors to historic sites, not to mention that it likely contributes to the perception about historic house museums that Ruth Graham highlights by asking "Do we have too many?"10 I can understand the argument that we do if they continue to operate as time capsules dedicated to freezing moments in history based on an extremely limited perspective which offers little room for additional insight, conflicts of critique, and the possibility that we do not know all there is to know about a subject (in every sense of that word) even if their life has concluded.

Virtual museums are uniquely positioned to overcome a number of the challenges that have faced historic house museums since their inception. First, and most practically, by translating their spaces, collections, and narratives into a virtual environment, they are no longer hampered by geographical distance or the expense of being forced to travel to a site. Visitors to these sites are afforded rich experiences to submerge themselves at their own pace, dwelling for as long as they like in what the site has to offer and returning as frequently as they desire. Physical museums rarely afford such luxuries. Furthermore, as an educator who cares deeply about what I consider the transformative potential of engaging with museums, their contents and ideas, I am delighted to be able to project virtual museums on the walls of my classroom to enliven and pique my students' interests even in the remote rural area where we live. For many of my students, learning about Cather online, for example, may well be their only opportunity, at least in the short term, to engage with the historic site and apply what they know about gender and sexuality in the late nineteenth and early twentieth century United States.

In cases of gender non-conformity and sexuality, we inhabit a world where these remain 
difficult, contentious issues to address and for individuals seeking role models, examples of other modes of living, historical antecedents, or just information in general, these sites serve an invaluable role. Perhaps it is time that we follow the lead of Frank Vagnone and Deborah Ryan, whose Anarchist's Guide to Historic House Museums (2015) advocates that we 'take bold steps' to remake these spaces into arenas of radical potential for new thought and social change, especially when we consider that their first run of books sold out in no time. That role could be inhabited by The Cather Foundation, and countless other historic sites with online presences (or those looking to create them) simply by relinquishing control of 'official' narratives and facilitating the delivery of multiple 'authoritative' ones. In the process of developing this new practice, queer people should be consulted for their perspectives to ensure that a range of possibilities and shared understandings receive representation and work to foster a sense of belonging and ownership with extends beyond the literal owners of these items and spaces. The Willa Cather Foundation enjoys the unique opportunity also to engage the numerous scholars and activists who have already dedicated serious time, energy, and thought to the problem of carefully, thoughtfully addressing Cather's gender non-conformity and sexuality. In fact, they need only consult a number of the resources available, though not featured or promoted, on their own website to begin this process. And finally, they might pioneer the end of the virtual closet - in part by collaborating with those who have helped shape narratives addressing gender non-conformity and sexuality at Beauport, Hull-House Museum, and The Museum of the Shenandoah Valley - and in the process become their own, much-needed queer pioneers.

Received: 18 June 2014

Finally accepted: 20 June 2017

\section{Notes}

1 Andrew Jewell and Janis Stout, '10 Things You Probably Didn't Know About Willa Cather', Publishers Weekly 19 Apr. 2013 https://www.publishersweekly.com/pw/by-topic/industrynews/tip-sheet/article/56879-10-things-you-probably-didn-t-know-about-willa-cather.html, accessed 25 June 25, 2017.

2 Joshua Adair (2015) 'Willa's Case: Queer Narratives and Virtual Museums.' The Apollonian 2(2) 1-12.

3 The museum, which includes Glen Burnie, a historic house in Winchester, Virginia, which its former owner Julian Wood Glass, Jr. refurbished with his then partner, R. Lee Taylor, opted to begin presenting the couple as gay since 2013. The biographies of both men, as well as photos of the impressive collection they amassed together can be found on the museum's virtual presence: www.themsv. org

4 Since 2008 guides at Beauport, a historic house in Gloucester, Massachusetts, built and decorated by one of the United States' first interior decorators, Henry Davis Sleeper, have been presenting Sleeper's sexuality to visitors. This change in practice was reportedly widely by the media and represents a significant shift in practice since this feature of Sleeper's life had been largely ignored in previous decades.

5 Hull-House Museum in Chicago, Illinois, pioneered discussions in the U.S. aboutsexuality in historic house museums, especially by asking visitors if Addams herself may have been a lesbian and then inviting them to consider the evidence, context, and potential interpretations. The site now offers a "Gender and Sexuality Tour" to "explore early $20^{\text {th }}$ century stories of gender non-conformity, diverse definitions of family, and fierce self-expression." www. hullhousemuseum.org

6 American Alliance of Museums, Welcoming Guidelines for Museums, http://aam-us.org/ docs/default-source/professional-networks/lgbtq_welcome_guide.pdf, accessed 25 June 2017. 
7 James H. Sanders III, 'Queering the Museums', CultureWork 2007. http://pages.uoregon. edu/culturwk/culturework37b.html, accessed 4 April 2016.

8 'About the Willa Cather Foundation', The Willa Cather Foundation 2016. https://www. willacather.org/about-willa-cather-foundation, accessed 4 April 2016.

9 Timothy Schaffert. 'Lesbian Ghosts of Red Cloud, Nebraska', Writers' Houses 2011. http:// writershouses.com/guest/the-lesbian-ghosts-of-red-cloud-nebraska, accessed 4April 2016.

10 Ruth Graham, 'The Great Historic House Museum Debate.' The Boston Globe 16 Nov. 2015. https://www.bostonglobe.com/ideas/2014/08/09/the-great-historic-house-museumdebate/jzFwE9tvJdHDCXehIWqK4O/story.html, accessed 4 Apr 2016.

\section{References}

Abraham, Julie (2008) Are Girls Necessary? Lesbian Writing and Modern Histories. Minneapolis: $U$ of MN Press, Print.

Adair, Joshua G. (2010) 'House Museums or Walk-In Closets? The (Non)Representation of Gay Men in the Houses They Called Home.' in Amy K. Levin, (ed), Gender, Sexuality and Museums: A Routledge Reader, 264-278, New York: Routledge.

Anders, John P (2001). Willa Cather's Sexual Aesthetics and the Male

Homosexual Literary Tradition. Lincoln: U of NE Press, 2001.

Butcher-Younghans, Sherry. (1996) Historic House Museums: A Handbook for Their Care, Preservation, and Management. New York: Oxford UP.

Eichstedt, Jennifer. (2006) 'Museums and (In)Justice.' in Hugh Genoways, (ed), Museum Philosophy for the Twenty-First Century, 130-142, Lanham, MD: AltaMira Press.

Ellis, Rex M. (2002) 'Interpreting the Whole House' in Jessica Foy Donnelly, (ed) Interpreting Historic House Museums, 61-80, New York, AltaMira Press

Giaccardi, Elisa. (2006) 'Collective Storytelling and Social Creativity in the

Virtual Museum.' Design Issues 22(3) 29-41.

Goldberg, Jonathan. (2001) Willa Cather and Others. Durham, NC: Duke UP.

Harris, Donna Ann. (2007) New Solutions for House Museums: Ensuring the

Long-Term Preservation of America's Historic Houses. New York: AltaMira Press

Lindemann, Marilee. (1999) Queering America. New York: Columbia UP.

Merritt, Jane and Julie A. Reilly. (2010) Preventive Conservation for Historic House Museums. New York: AltaMira Press.

O'Brien, Sharon. (1987) Willa Cather: The Emerging Voice. New York: Oxford UP.

Porter, David. (2008) On the Divide: The Many Lives of Willa Cather. Lincoln: U of NE Press.

Romesburg, Don. (2014) 'Presenting the Queer Past: A Case for the GLBT History Museum.' Radical History Review 120, 131-144 
Srinivasan, Ramesh, Robin Boast, Jonathan Furner, and Katherine M. Becvar. (2009) 'Digital Museums and Diverse Cultural Knowledges: Moving Past the Traditional Catalog.' The Information Society 25, 265-278

Youngs, Renae, Christopher Leitch, and Michael Lesperance. (2016) 'Setting the Standard for LGBTQ Inclusion.' Museum, 33-35.

*Joshua Adair is an associate professor of English at Murray State University, where he also serves as director of the Racer Writing Center and coordinator of Gender \& Diversity Studies. His work primarily focuses upon narratives of queerness and has appeared in Gender and Sexuality in Museums (Routledge, 2010), Interdisciplinary Literary Studies, Notches, and others. His collection, co-edited with Amy K. Levin, Defining Memory: Local Museums and the Construction of History in America's Changing Communities, Second Edition, is due out later this year from Rowman \& Littlefield.

Josh Adair, PhD, Assistant Professor, Department of English and Philosophy

Director, Racer Writing Center

Coordinator, Gender and Diversity Studies

Co-Coordinator, Safe Zone Project

7B-14 Faculty Hall

Murray State University

Murray, KY 42071

jadair1@murraystate.edu

270-809-4540

libguides.murraystate.edu/writingcenter

www.murraystate.edu/gds 